\title{
Alfabetización profesional durante la carrera universitaria: entre la universidad y la empresa
}

\author{
Lucía Natale y Daniela Stagnaro(1)
}

Palabras clave. alfabetización profesional . géneros $\cdot$ escritura $\cdot$ ingeniería

Resumen. Las prácticas de escritura en la universidad y su enseñanza se han convertido en uno de los objetos privilegiados de diferentes disciplinas que han ido conformando este nuevo campo de interés. Este trabajo tiene como propósito principal presentar algunos resultados parciales de una investigación llevada a cabo alrededor de las prácticas de escritura del campo de la ingeniería industrial. En el marco del Programa para el Desarrollo de Habilidades de Lectura y Escritura a lo largo de la Carrera (PRODEAC) de una universidad pública argentina, relevamos los géneros utilizados en el ámbito empresarial a partir de encuestas a ingenieros y consultamos a estudiantes que participan del ámbito académico y del profesional sobre los textos demandados en ambos ámbitos. De esta forma, observamos si la preparación de los estudiantes contempla los desempeños escriturales que se demandan en la vida profesional. A diferencia de los hallazgos de estudios previos realizados en universidades de España y Chile, encontramos que de los treinta y tres géneros relevados del ámbito empresarial la universidad se ha ocupado de veinte de ellos en el transcurso del segundo ciclo de la carrera de Ingeniería Industrial y hemos identificado los géneros que será necesario describir e incluir en los diseños pedagógicos de las asignaturas.
Keywords. professional literacy $\cdot$ genres . writing; Engineering

Abstract. Writing practices and the teaching of writing in the university level is a growing research area in which scholars of different disciplines work. This paper presents some partial results of an ongoing research project about writing practices in the Industrial Engineering field. As part of the activities of the Institutional Program for teaching academic and professional literacy across the University curriculum (PRODEAC) developed at a nacional university, we surveyed a group of engineers and students in order to analyse the genres employed in professional settings. For this reason, we asked students working in different companies to tell us which genres they had already used at work and in the university assignments. In contrast with the findings of previous research work carried out in Spain and Chile, we have found out that students in different courses produced 20 of the 33 genres required in the companies and we have also identified the genres we need to describe and include them in the pedagogical designs of the subjects.

(1) Lucía Natale lnatale@ungs.edu.ar y Daniela Stagnaro dstagnar@ungs.edu.ar. PRODEAC, Universidad Nacional de General Sarmiento. 